\title{
Perubahan Karakteristik Pangan Tradisional Pesan Tlengis Selama Penyimpanan Suhu Ruang
}

\section{Characteristics Changes of Traditional Food Pesan Tlengis During Room Temperature Storage}

\author{
Desak Nyoman Anggreni Bhaskara ${ }^{1}$, Luh Putu Trisna Darmayanti ${ }^{1{ }^{*}}$, I Putu Suparthana $^{1}$ \\ Program Studi Teknologi Pangan, Fakultas Teknologi Pertanian, Universitas Udayana \\ Kampus Bukit Jimbaran, Badung-Bali \\ *Penulis korespondensi: Luh Putu Trisna Darmayanti, Email: trisnadarmayanti@unud.ac.id
}

\begin{abstract}
Pesan tlengis is one of Balinese foods made from tlengis or blondo, which is a waste from the process of producing coconut oil in the form of white sediment. In general, the process of producing pesan tlengis is that the tlengis was added with basa genep (complete seasoning), wrapped in banana leaves, and then roasted. Pesan Tlengis was damaged when stored at room temperature of $25^{\circ} \mathrm{C}-30^{\circ} \mathrm{C}$, with storage time above 12 hours. Pesan tlengis was damaged during storage at room temperature due to the high content of nutrients such as fat, protein, and water. The high nutrient content in pesan tlengis can be reduced by adding a steaming process. This study was aimed to determine the changes in the characteristics of pesan tlengis during storage at room temperature and to find out how long pesan tlengis can still be consumed during storage at room temperature. This study used a completely randomized design (CRD) with storage time treatment consisting of 4 levels, namely T0 (0 hours), T1 (24 hours), T2 (48 hours), and T3 (72 hours). The data obtained were analyzed by analysis of variance (ANOVA) and if there was a significant effect between treatment levels, it was followed with Duncan's Multiple Range Test. The results showed that the storage time of pesan tlengis at room temperature had a significant effect on moisture content, ash content, protein content, fat content, carbohydrate content, total microbial plate, total mold and yeast, total coliform, texture and aroma. Storage time of 24 hours was the period of time when pesan tlengis can still be consumed with a moisture content value of $5.40 \%$, ash content $3.13 \%$, protein content $12.2 \%$, fat content $55.08 \%$, carbohydrate content $24.71 \%$, total microbial plate $5.99 \log \mathrm{cfu} / \mathrm{ml}$, total mold and yeast $0 \mathrm{log} \mathrm{cfu} / \mathrm{ml}$, negative coliform, ordorless sour aroma, and the texture slightly slimy.
\end{abstract}

Keywords: traditional food, room temperature storage, pesan tlengis, tlengis or blondo

\section{PENDAHULUAN}

Pesan tlengis adalah salah satu pangan tradisional khas Bali yang berbahan dasar tlengis atau blondo, yang merupakan limbah dari proses pembuatan minyak kelapa. Tlengis atau blondo memiliki karakteristik warna putih terksturnya seperti krim dan dalam waktu empat hari akan mengeluarkan bau yang tidak sedap dan menyengat (Haerani, 2010). Pesan tlengis sangat digemari di masyarakat karena rasanya yang gurih, harganya yang relatif murah dan memiliki kandungan gizi yang cukup tinggi. Kandungan gizi yang terdapat di dalam tlengis atau blondo seperti, karbohidrat, lemak, protein, abu, vitamin A, kalium, yodium, kalsium, dan phosphor.

Pada umumnya proses pembuatan pesan tlengis yaitu tlengis ditambahkan base genep (bawang putih, bawang merah, cabai, kunyit, lengkuas, jahe, kencur, ketumbar, merica, pala, kemiri, garam, terasi), dibungkus dengan menggunakan daun pisang, dan dipanggang. Pesan Tlengis cepat mengalami kerusakan apabila disimpan pada suhu ruang $25^{\circ} \mathrm{C}-30^{\circ} \mathrm{C}$ dengan lama penyimpanan diatas 12 jam (Anon., 2019). 
Kerusakan yang ditimbulkan pesan tlengis seperti perubahan aroma menjadi asam dan tekstur menjadi lunak (berlendir). Penyebab kerusakan yang ditimbulkan pada pesan tlengis selama penyimpanan suhu ruang adalah tingginya kandungan gizi pada pesen tlengis seperti lemak, protein, dan air. Tingginya kandungan gizi yang terdapat pada pesan tlengis maka dapat dikurangi dengan menambahkan proses pengukusan. Tujuan dari menambahkan proses pengukusan agar pesan tlengis memiliki masa simpan yang lebih tahan lama apabila disimpan pada suhu ruang.

Menurut Julinar, et al., (2005) untuk memperpanjang masa simpan pada produk agar tetap memiliki kandungan gizi yang cukup tinggi yaitu dengan menggunakan metode pengukusan. Pengukusan dapat mempengaruhi karakteristik produk seperti flavor dan tekstur (Lewis, 2006 dalam Intan, et al., 2018). Fatimah dan Sandri, (2016), menyatakan pengukusan dapat memperpanjang masa simpan pada produk getuk pisang rainbow selama penyimpanan 2 hari berdasarkan penerimaan panelis dan penentuan jumlah mikroba.

Berdasarkan dari permasalahan tersebut maka peneliti melakukan perbaikan produk dengan menambahkan proses pengukusan. Tujuan dari penelitian ini dapat mengetahui pengaruh perubahan karakteristik pada pesan tlengis originil selama penyimpanan pada suhu ruang, serta memberikan informasi kepada masyarakat mengenai berapa lama pesan tlengis masih dapat untuk dikonsumsi.

\section{METODE PENELITIAN}

\section{Tempat dan Waktu Penelitian}

Penelitian ini dilaksanakan di Laboratorium Mikrobiologi Pangan dan Laboratorium Analisis Pangan, Universitas Udayana Jalan Jendral Sudirman Denpasar. Pelaksanaan penelitian ini dilakukan pada bulan Maret hingga Juli 2020.

\section{Alat dan Bahan}

Alat yang digunakan dalam penelitian ini adalah cawan aluminium, cawan porselin, oven, desikator, kompor listrik (Maspion), tabung reaksi, pipet tetes, tabung reaksi besar (Pyrex), soxhlet, bola hisap, pipet volum $5 \mathrm{ml}$, Erlenmeyer $25 \mathrm{ml}$, labu lemak (Pyrex), kertas saring, benang woll, petri, pinset, spatula, laminar air flow, inkubator, batang gelas bengkok (Pyrex), petri, gelas baker, kapas, aluminium foil, batang pengaduk, bunsen, Erlenmeyer (Pyrex), autoclave (Hiclave HVE-5 0), plastik anti panas, muffle (Daihan), biuret (Pyrex),timbangan analitik (Shimadzu), gelas ukur (Pyrex).

Bahan yang digunakan dalam penelitian ini adalah tlengis, daun pisang, tablet kjeldahl, $\mathrm{H}_{2} \mathrm{SO}_{4}$, aquadest, $\mathrm{NaOH} 50 \%$, penolphatalin (PP), asam borat 3\%, HCL 0,1N, heksan teknis, Lactose Broth, Plate Count Agar (Oxoid), Plate Dextrose Agar (Oxoid), Pepton Water (Merck), alkohol.

\section{Rancangan Penelitian}

Rancangan percobaan yang digunakan pada penelitian ini adalah Rancangan Acak Lengkap (RAL) dengan perlakuan lama penyimpanan terdiri dari 4 taraf, yaitu :T0 $=0$ jam; $\mathrm{T} 1=24$ jam; T2 = 48 jam; T3 = 72 jam. Masing-masing perlakuan diulang sebanyak 4 kali sehingga diperoleh 16 unit percobaan. Data yang diperoleh dianalisis dengan 
analisis ragam (Analysis of Variance/ANOVA) dan apabila terdapat pengaruh nyata antar taraf perlakuan maka dilanjutkan dengan Uji Jarak Berganda Duncan (Gomez dan Gomez, 1995)

\section{Pelaksanaan Penelitian}

Pelaksanaan penelitian terdiri dari beberapa tahapan yaitu :

\section{Survey Produsen Pesan Tlengis}

Sebelum melakukan penelitian, peneliti melakukan survey terlebih dahulu kepada produsen pesan tlengis di daerah Desa Dauh Puri Klod, Kecamatan Denpasar Barat. Survey yang dilakukan dengan mengajukan beberapa pertanyaan menggunakan kusioner. Hasil dari kusioner dijadikan acuan dalam memperbaiki produk.

\section{Pembuatan Pesan Tlengis}

Pembuatan pesan tlengis diawali dengan membeli tlengis pada produsen minyak kelapa yang berjualan di Pasar Sanglah. Tlengis yang sudah didapatkan diolah sesuai dengan proses pembuatan pesan tlengis yang sudah dimodifikasi. Adapun diagram alir proses pembuatan pesan tlengis sebagai berikut, tlengis atau blondo yang didapat pada produsen minyak kelapa ditambahkan base genep, dibungkus menggunakan daun pisang, dikukus selama \pm 15 menit, pesan tlengis diangkat dan dipangggang selama \pm 2 menit.

\section{Variabel yang Diamati}

Variabel yang diamati dalam penelitian ini adalah kadar air (Sudarmadji et al., 1997), kadar abu (Sudarmadji et al., 1997), kadar protein (Sudarmadji et al., 1997), kadar lemak (Sudarmadji et al., 1997)., kadar karbohidrat by difference (Sudarmadji et al., 1997), angka lempeng total mikroba (Buckle, 1987), angka kapang khamir (Buckle, 1987), total koliform (Cappucino dan Sherman, 1992) dan uji sensori menggunakan uji skoring meliputi aroma dan tekstur (Soekarto,1985).

\section{HASIL DAN PEMBAHASAN}

Perubahan karakteristik pada pesan tlengis selama penyimpanan suhu ruang terdiri dari kadar air, kadar abu, kadar protein, kadar lemak, kadar karbohidrat, angka lempeng total mikroba, angka kapang khamir, dan total koliform. Adapun nilai rata-rata dari kadar air, kadar abu, kadar protein dapat dilihat pada Tabel 1.

Tabel 1. Nilai Rata-rata dari Kadar Air, Kadar Abu, dan Kadar Protein pada Pesan Tlengis Selama Penyimpanan Suhu Ruang

\begin{tabular}{lccc}
\hline Lama Penyimpanan & Kadar Air $(\%)$ & Kadar Abu (\%) & Kadar Protein $(\%)$ \\
\hline T0 $(0$ jam $)$ & $4,80 \mathrm{a} \pm 0,11$ & $3,82 \mathrm{~b} \pm 0,38$ & $14,55 \mathrm{c} \pm 0,59$ \\
T1 $(24$ jam $)$ & $5,04 \mathrm{~b} \pm 0,21$ & $3,55 \mathrm{ab} \pm 0,34$ & $13,77 \mathrm{bc} \pm 0,87$ \\
T2 $(48$ jam $)$ & $5,08 \mathrm{~b} \pm 0,08$ & $3,18 \mathrm{a} \pm 0,42$ & $12,87 \mathrm{ab} \pm 1,59$ \\
T3 $(72$ jam $)$ & $5,11 \mathrm{~b} \pm 0,57$ & $3,10 \mathrm{a} \pm 0,28$ & $12,16 \mathrm{a} \pm 0,46$ \\
\hline
\end{tabular}

Keterangan : Huruf yang sama dibelakang nilai rata-rata pada kolom yang sama menunjukkan perlakuan tidak berbeda nyata $(\mathrm{P}>0,05)$

\section{Kadar Air}

Hasil analisis ragam menunjukan lama penyimpanan berpengaruh nyata $(\mathrm{P}<0,05)$ terhadap kadar air. Tabel 1 menunjukkan nilai ratarata kadar air pesan tlengis selama penyimpanan suhu ruang berkisar antara 4,80\% - 5,11\%. Nilai 
kadar air tertinggi diperoleh lama penyimpanan T3 (72 jam) yaitu sebesar 5,11\%, sedangkan yang terendah diperoleh dari lama penyimpanan T0 $(0$ jam) yaitu sebesar 4,80\%. Lama penyimpanan $\mathrm{T} 3$ (72 jam) tidak berbeda nyata dengan T1 (24 jam) dan T2 (48 jam).

Menurut Jamasuta, et al., (1996) yang menyatakan bahwa pengukusan dapat menguapkan air lebih besar daripada perebusan. Proses pengukusan dapat menguapkan kadar air pada produk, sehingga selama pengukusan kadar air pada produk mengalami penurunan. Seiring bertambahnya lama penyimpanan, pesan tlengis mengalami peningkatan kadar air. Terjadinya peningkatan kadar air pada pesan tlengis disebabkan oleh kondisi lingkungan seperti suhu udara pada ruangan sehingga masuknya udara melalui pori-pori produk selama penyimpanan dan adanya aktivitas mikroba. Hal ini sejalan dengan pendapat Winarno dan Betty, (1983) menjelaskan bahwa kadar air selama penyimpanan sangat dipengaruhi oleh kelembaban relatif udara sekitar bahan. Kadar air yang tinggi dapat menyebabkan produk lebih mudah mengalami kerusakan dikarenakan adanya mikroba pembusuk yang memanfaatkan air pada produk sebagai media pertumbuhannya. Semakin tinggi kadar air maka mikroba dengan mudah untuk berkembang biak sehingga produk pangan akan mengalami perubahan baik secara fisik, kimia maupun mikrobiologi (Winarno, 1997). Menurut SNI 014309-1996 pada kue basah batas maksimal kadar air sebesar $40 \%$, sehingga kadar air dari pesan tlengis selama penyimpanan pada suhu ruang masih memenuhi syarat SNI.

\section{Kadar Abu}

Hasil analisis ragam menunjukkan bahwa lama penyimpanan pesan tlengis pada suhu ruang berpengaruh nyata $(\mathrm{P}<0,05)$ terhadap kadar abu. Tabel 1 menunjukkan nilai rata-rata kadar abu pesan tlengis selama penyimpanan suhu ruang berkisar antara 3,10\% - 3,82\%. Nilai kadar abu tertinggi diperoleh lama penyimpanan T0 (0 Jam) yaitu, sebesar 3,82\% dan terendah diperoleh dari lama penyimpanan T3 (72 jam) yaitu, sebesar 3,10\%. Lama penyimpanan T3 (72 jam) tidak berbeda nyata dengan T1 (24 jam) dan T2 (48 jam).

Semakin lama penyimpanan pada suhu ruang, kadar abu pesan tlengis mengalami penurunan karena adanya aktivitas mikroba yang membutuhkan mineral untuk berkembangbiak. Hal ini sejalan dengan pendapat Putri, et al., (2017) yang menyatakan bahwa mikroba membutuhkan mineral untuk mempertahankan hidup. Selama penyimpanan terjadi peningkatan aktivitas air pada umumnya akan diikuti oleh pertumbuhan mikroba baik bakteri ataupun kapang.

\section{Kadar Protein}

Hasil analisis ragam menunjukkan lama penyimpanan berpengaruh nyata $(\mathrm{P}<0,05)$ terhadap kadar protein. Tabel 1 menunjukkan nilai rata-rata kadar protein pesan tlengis selama penyimpanan suhu ruang berkisar antara $12,16 \%$ $14,55 \%$. Nilai kadar protein tertinggi diperoleh dari lama penyimpanan T0 (0 jam) yaitu, sebesar 14,55\%, sedangkan terendah T3 (72 jam) sebesar $12,16 \%$. Lama penyimpanan T0 (0 jam) berbeda nyata dengan T2 (48 jam) dan T3 (72 jam).

Pesan tlengis selama penyimpanan pada suhu ruang mengalami penurunan kadar protein. 
Penurunan kadar protein disebabkan karena adanya proses pengukusan serta dilanjutkan dengan proses pemanggangan yang menyebabkan denaturasi protein, selain itu kadar protein dalam produk sebagai sumber nutrisi bagi mikroba untuk pertumbuhan. Hal ini sejalan dengan pendapat Winarno, 2008 dalam Sipayung, et al., (2015) menyatakan protein mengalami denaturasi dapat disebabkan oleh beberapa faktor, yaitu panas, $\mathrm{pH}$, bahan kimia, dan mekanik. Menurut Purnawijayanti (2001), makanan berprotein yang telah mengalami kerusakan menghasilkan bau busuk khas protein, tekstur lebih lembek dan berlendir. Menurut Dyah (2017), faktor terjadinya penurunan protein akibat dari lama penyimpanan yaitu kelembaban udara dan tingginya pertumbuhan mikroba selama proses penyimpanan karena mikroba mendegradasi protein untuk dijadikan sumber nutrisi bagi pertumbuhan sehingga menimbulkan penurunan kadar protein.

Tabel 2. Nilai Rata-rata dari Kadar Lemak dan Kadar Karbohidrat pada Pesan Tlengis Selama Penyimpanan Suhu Ruang

\begin{tabular}{lcc}
\hline \multicolumn{1}{c}{ Lama Penyimpanan } & Kadar Lemak $(\%)$ & Kadar karbohidrat (\%) \\
\hline T0 $(0$ jam $)$ & $56,85 \mathrm{c} \pm 2,66$ & $20,59 \mathrm{a} \pm 3,21$ \\
T1 $(24$ jam $)$ & $55,83 \mathrm{bc} \pm 1,66$ & $21,79 \mathrm{a} \pm 1,37$ \\
T2 $(48$ jam $)$ & $52,99 \mathrm{ab} \pm 1,36$ & $26,00 \mathrm{~b} \pm 2,07$ \\
T3 $(72$ jam $)$ & $52,2 \mathrm{a} \pm 2,00$ & $26,79 \mathrm{~b} \pm 2,02$ \\
\hline
\end{tabular}

Keterangan : Huruf yang sama dibelakang nilai rata-rata pada kolom yang sama menunjukkan perlakuan tidak berbeda nyata $(\mathrm{P}>0,05)$

\section{Kadar Lemak}

Hasil analisis ragam menunjukkan bahwa lama penyimpanan berpengaruh nyata $(\mathrm{P}<0.05)$ terhadap kadar lemak. Tabel 2 menunjukkan nilai rata-rata kadar lemak pesan tlengis selama penyimpanan suhu ruang berkisar antara 52,23\% $56,85 \%$. Nilai rata-rata kadar lemak tertinggi diperoleh dari lama penyimpanan T0 ( 0 jam) yaitu, sebesar $56,85 \%$, sedangkan nilai terendah terendah dari lama penyimpanan T3 (72 Jam) yaitu, sebesar 52,23\%. Lama penyimpanan T0 (0 jam) tidak berbeda nyata dengan T1 (24 jam) dan T3 (72 Jam) tidak berbeda nyata dengan T2 (48 jam).

Pesan tlengis mengalami penurunan kadar lemak selama penyimpanan pada suhu ruang. Penurunan kadar lemak pada pesan tlengis disebabkan oleh adanya aktivitas mikroba dan lemak teroksidasi selama penyimpanan pada suhu ruang. Hal ini sejalan dengan pendapat Dyah, (2017) yang menyatakan bahwa kerusakan bahan pangan pada lemak jika terlihat kuning, menggumpal, muncul aroma tengik dan rasa asam. Aroma tengik diakibatkan oleh aktivitas enzim pada bahan yang mengandung lemak dan aktivitas mikroba yang terkandung dalam lemak atau oksidasi. Semakin lama penyimpanan dapat mengakibatkan penurunan kadar lemak, penurunan kadar lemak disebabkan oleh oksidasi pada krim susu (Kusrahayu, et al., 2009) .

\section{Kadar Karbohidrat}

Hasil analisis ragam menunjukkan bahwa lama penyimpanan berpengaruh nyata $(\mathrm{P}<0.05)$ terhadap kadar karbohidrat. Tabel 2 menunjukkan nilai rata-rata kadar karbohidrat pesan tlengis 
selama penyimpanan pada suhu ruang berkisar antara 20,59\% - 26,79\%. Nilai kadar karbohidrat tertinggi pada lama penyimpanan T3 (72 Jam) yaitu, sebesar 26,79\%, sedangkan kadar karbohidrat terendah pada lama penyimpanan $\mathrm{T} 0$ (0 Jam) yaitu, sebesar 20,59\%. Lama Penyimpanan T0 (0 jam) berbeda nyata dengan T2 (48 jam) dan T3 (72 jam).

Kadar karbohidrat diperoleh berdasarkan metode by difference yang dipengaruhi oleh nilai dari kadar air, kadar abu, kadar protein dan kadar lemak. Pengingkatan kadar karbohidrat pada pesan tlengis selama penyimpanan disebabkan oleh penggunaan metode by difference. Hal ini sejalan dengan kadar karbohidrat mengalami peningkatan dipengaruhi oleh faktor pengurangan dari kadar air, kadar abu, kadar protein dan kadar lemak (Soputan, et al., 2016). Kadar karbohidrat dengan menggunakan metode by difference dipengaruhi oleh kadar air, kadar abu, kadar protein dan kadar lemak, sehingga dengan meningkatnya kandungan gizi tersebut dapat menurunkan kadar karbohidrat pada produk sagu mutiara dengan penambahan buah kenari (Lawalata, 2004).

\section{Angka Lempeng Total Mikroba}

Adapun hasil analisis ragam dari angka lempeng total mikroba dilihat pada Tabel 3 . Perubahan angka lempeng total mikroba pesan tlengis selama penyimpanan pada suhu ruang dapat dilihat pada Tabel 4.

Tabel 3. Hasil Analisis Ragam Angka Lempeng Total Mikroba pada Pesan Tlengis Selama Penyimpanan Suhu Ruang

\begin{tabular}{|c|c|}
\hline Lama Penyimpanan & $\begin{array}{c}\text { Angka Lempeng Total Mikroba } \\
\text { (Log CFU/g) }\end{array}$ \\
\hline T0 (0 jam) & $1,04 \mathrm{a} \pm 2,08$ \\
\hline $\mathrm{T} 1(24 \mathrm{jam})$ & $5,99 b \pm 0,03$ \\
\hline $\mathrm{T} 2(48$ jam $)$ & $7,12 b \pm 0,49$ \\
\hline $\mathrm{T} 3(72$ jam $)$ & $7,18 b \pm 0,02$ \\
\hline
\end{tabular}

Keterangan : Huruf yang sama dibelakang nilai rata-rata pada kolom yang sama menunjukkan perlakuan tidak berbeda nyata $(\mathrm{P}>0,05)$

Tabel 4. Angka Lempeng Total Mikroba pada Pesan Tlengis Selama Penyimpanan pada Suhu Ruang

\begin{tabular}{lccc}
\hline $\begin{array}{c}\text { Lama } \\
\text { Penyimpanan }\end{array}$ & $\begin{array}{c}\text { Angka Lempeng Total } \\
\text { Mikroba } \\
\text { (CFU/g) }\end{array}$ & $\begin{array}{c}\text { Standard SNI } \\
01-4309-1996\end{array}$ & Keterangan \\
\hline T0 $(0$ jam $)$ & $0,03 \times 10^{5} \mathrm{cfu} / \mathrm{g}$ & & Memenuhi syarat \\
T1 $(24 \mathrm{jam})$ & $0,98 \times 10^{6} \mathrm{cfu} / \mathrm{g}$ & $1 \times 10^{6} \mathrm{koloni} / \mathrm{g}$ & $\begin{array}{c}\text { Memenuhi syarat } \\
\text { T2 }(48 \mathrm{jam})\end{array}$ \\
T3 $(72 \mathrm{jam})$ & $7,57 \times 10^{6} \mathrm{cfu} / \mathrm{g}$ & & Tidak memenuhi syarat \\
& $1,51 \times 10^{7} \mathrm{cfu} / \mathrm{g}$ & & \\
\hline
\end{tabular}

Hasil analisis ragam menunjukkan lama penyimpanan pesan tlengis pada suhu ruang berpengaruh nyata $(\mathrm{P}<0.05)$ terhadap angka lempeng total mikroba. Tabel 3, menunjukan bahwa semakin lama penyimpanan, pesan tlengis mengalami peningkatan angka lempeng total mikroba. Lama penyimpanan T1 (24 jam), T2 (48 jam) dan T3 (72 jam) tidak berbeda nyata. Berdasarkan hasil pengujian nilai rata-rata angka lempeng total mikroba pada pesan tlengis selama 
penyimpanan suhu ruang berkisar antara $0,03 \times 10^{5}$ cfu/g sampai dengan $1,51 \times 10^{7} \mathrm{cfu} / \mathrm{g}$ (Tabel 4).

Pesan tlengis memiliki nutrisi (protein, lemak, karbohidrat, abu) yang tinggi dan meningkatnya kadar air selama proses penyimpanan maka memberikan peluang bagi mikroba pembusuk untuk membelah diri lebih banyak sehingga angka lempeng total mikroba mengalami peningkatan seiring bertambahnya lama penyimpanan. Hal ini sejalan dengan Winarno, (1994) yang menyatakan bahwa mikroba mampu hidup hampir di semua tempat dan mampu bertahan dalam berbagai keadaan lingkungan, baik pada suhu, tekanan, $\mathrm{pH}$, tingkat osmosis serta kadar air yang ekstrim. Menurut Dyah, (2017) proses terjadinya kerusakan mikrobiologis pada bahan pangan yaitu, bahan pangan disimpan dalam suhu ruang $\left( \pm 28^{\circ} \mathrm{C}\right)$ sehingga terjadi metabolisme mikroba seperti mengeluarkan toksin atau racun yang menyebabkan kerusakan makanan dan akan berbahaya jika dikonsumsi. Suhu optimum pertumbuhan mikroba adalah $20^{\circ} \mathrm{C}-40^{\circ} \mathrm{C}$.

Persyaratan maksimal mikroba pada kue basah sesuai SNI 01-4309-1996 adalah 1 × $10^{6}$ koloni/g, sehingga sampel pesan tlengis pada lama penyimpanan T0 (0 jam) dan T1 (24 jam) memenuhi persyaratan mutu kue basah dengan nilai angka lempeng total mikroba berkisar $0,03 \mathrm{x}$ $10^{5} \mathrm{cfu} / \mathrm{g}$ sampai dengan $0,98 \times 10^{6} \mathrm{cfu} / \mathrm{g}$, sedangkan lama penyimpanan T2 (48 jam) dan T3 (72 jam) tidak memenuhi persyaratan mutu kue basah dengan nilai angka lempeng total mikroba berkisar $7,57 \times 10^{6} \mathrm{cfu} / \mathrm{g}$ sampai dengan $1,51 \times 10^{7}$ cfu/g.

\section{Angka Kapang Khamir}

Adapun hasil analisis ragam dari angka kapang khamir dilihat pada Tabel 5. Perubahan angka kapang khamir pesan tlengis selama penyimpanan pada suhu ruang dapat dilihat pada Tabel 6.

Tabel 1. Hasil Analisis Ragam dari Angka Kapang Khamir pada Pesan Tlengis Selama Penyimpanan Suhu Ruang

\begin{tabular}{cc}
\hline Lama Penyimpanan & $\begin{array}{c}\text { Angka Kapang Khamir } \\
(\text { Log CFU/ g) }\end{array}$ \\
\hline T0 $(0$ jam $)$ & $0,00 \mathrm{a} \pm 0,00$ \\
T1 $(24$ jam $)$ & $0,00 \mathrm{a} \pm 0,00$ \\
T2 $(48$ jam $)$ & $6,57 \mathrm{~b} \pm 0,12$ \\
T3 $(72$ jam $)$ & $6,93 \mathrm{c} \pm 0,02$ \\
\hline
\end{tabular}

Keterangan : Huruf yang sama dibelakang nilai rata-rata pada kolom yang sama menunjukkan perlakuan tidak berbeda nyata $(\mathrm{P}>0,05)$

Tabel 6. Angka Kapang Khamir Pesan Tlengis Selama Penyimpanan pada Suhu Ruang

\begin{tabular}{lccc}
\hline Lama Penyimpanan & $\begin{array}{c}\text { Angka Kapang Khamir } \\
\text { CFU } / \mathrm{g}\end{array}$ & $\begin{array}{c}\text { Standard SNI } \\
01-4309-1996\end{array}$ & Keterangan \\
\hline T0 $(0 \mathrm{jam})$ & $0 \mathrm{cfu} / \mathrm{g}$ & & Memenuhi syarat \\
T1 $(24 \mathrm{jam})$ & $0 \mathrm{cfu} / \mathrm{g}$ & $1 \times 10^{4} \mathrm{koloni} / \mathrm{g}$ & $\begin{array}{c}\text { Memenuhi syarat } \\
\text { T2 }(48 \mathrm{jam})\end{array}$ \\
$\begin{array}{l}3,9 \times 10^{6} \mathrm{cfu} / \mathrm{g} \\
\text { T3 }(72 \mathrm{jam})\end{array}$ & & Tidak memenuhi syarat \\
\hline
\end{tabular}


Hasil analisis ragam menunjukkan lama penyimpanan pesan tlengis selama penyimpananan suhu ruang berpengaruh nyata $(\mathrm{P}<0.05)$ terhadap angka kapang khamir. Tabel 6, menunjukan bahwa semakin lama penyimpanan, pesan tlengis mengalami peningkatan angka kapang khamir. Berdasarkan hasil pengujian nilai rata-rata angka kapang khamir pada pesan tlengis selama penyimpanan suhu ruang berkisar antara $0 \mathrm{cfu} / \mathrm{g}$ sampai dengan $8,6 \times 10^{6} \mathrm{cfu} / \mathrm{g}$. Lama penyimpanan T0 (0 jam) dan T1 (24 jam) tidak berbeda nyata.

Angka kapang khamir pesan tlengis selama penyimpanan pada suhu ruang mengalami peningkatan dikarenakan pesan tlengis memiliki kandungan nutrisi yang cukup tinggi, adanya oksigen, meningkatnya kadar air mampu membantu pertumbuhan kapang khamir yang tumbuh pada suhu optimum $25^{\circ} \mathrm{C}-30^{\circ} \mathrm{C}$ tetapi beberapa dapat tumbuh pada suhu $35^{\circ} \mathrm{C}-37^{\circ} \mathrm{C}$. Hal ini sejalan dengan Ahmad, (2005) bahwa reproduksi khamir dipengaruhi oleh kondisi lingkungan dan nutrisi yang tersedia dalam substrat yaitu gula sederhana, karbohidrat, nitrogen, dan oksigen, sedangkan menurut Waluyo, (2004) kapang mampu tumbuh pada bahan yang mengandung pati, pektin, protein atau lipid.

Persyaratan maksimal angka kapang khamir pada kue basah sesuai SNI 01-4309-1996 adalah 1 x $10^{4} \mathrm{cfu} / \mathrm{g}$, sehingga sampel pesan tlengis pada lama penyimpanan T0 (0 jam) dan T1 (24 jam) masih memenuhi persyaratan mutu kue basah dengan nilai angka kapang khamir $0 \mathrm{cfu} / \mathrm{g}$, sedangkan lama penyimpanan T2 (48 jam) dan T3 (72 jam) tidak memenuhi persyaratan mutu kue basah dengan nilai angka kapang khamir berkisar $3,9 \times 10^{6} \mathrm{cfu} / \mathrm{g}$ sampai dengan $8,6 \times 10^{6} \mathrm{cfu} / \mathrm{g}$.

\section{Total Koliform}

Analisis total koliform dengan media Lactose Broth (LB) selama 48 jam. Dihitung dengan perhitungan tabel Most Probable Number (MPN) atau Angka Paling Mungkin (APM) yang menggunakan tiga seri tabung (Cappucino dan Sherman, 1992). Pengenceran seri dilakukan untuk mengurai kerapatan pertumbuhan koloni mikroba pada sampel yang akan diuji. Adapun data koliform pada pesan tlengis selama penyimpanan pada suhu ruang dapat dilihat pada Tabel 7.

Tabel 7. Data Koliform pada Pesan Tlengis Selama Penyimpanan Suhu Ruang

\begin{tabular}{crrrc}
\hline Lama Penyimpanan & Seri A & \multicolumn{1}{c}{ Seri B } & Seri C & Uji Koliform MPN/APM (koloni/g) \\
\hline T0 $(0$ jam $)$ & 0 & 0 & 0 & $<3,0$ \\
T1 $(24$ jam $)$ & 0 & 0 & 0 & $<3,0$ \\
T2 $(48$ jam $)$ & 0 & 0 & 0 & $<3,0$ \\
T3 $(72$ jam $)$ & 0 & 0 & 0 & $<3,0$ \\
\hline
\end{tabular}

Keterangan : Nilai 0 pada seri A, B dan C menandakan negatif koliform.

Pengujian penyimpanan pesan tlengis pada suhu ruang hingga 72 jam didapatkan hasil tidak timbul gas pada tabung durham dan dapat dinyatakan negatif (bernilai 0). Hal ini menandakan pesan tlengis tidak terdapat koliform.
Pernyataan tersebut sejalan dengan penelitian Misbah, et al (2015) menyatakan tidak terdapat gelembung gas di dalam tabung durham sehingga pada penelitian kajian mutu dan keamanan pangan sate bulayak dinyatakan negatif koliform. 


\section{Uji Sensori}

Pengujian sensori menggunakan metode skoring meliputi, tekstur dan aroma. Adapun nilai rata-rata dari uji skoring tekstur dan aroma dapat dilihat pada Tabel 8.

Tabel 8. Nilai Rata-rata Uji Skoring Tekstur dan Aroma pada Pesan Tlengis Selama Penyimpanan Suhu Ruang

\begin{tabular}{ccc}
\hline Lama Penyimpanan & Tekstur & Aroma \\
\hline T0 $(0$ jam $)$ & $1,56 \mathrm{a} \pm 0,50$ & $2,12 \mathrm{a} \pm 0,60$ \\
T1 $(24$ jam $)$ & $2,36 \mathrm{~b} \pm 0,48$ & $3,16 \mathrm{~b} \pm 0,74$ \\
T2 $(48$ jam $)$ & $3,68 \mathrm{c} \pm 0,55$ & $3,92 \mathrm{c} \pm 0,75$ \\
T3 $(72$ jam $)$ & $4,2 \mathrm{~d} \pm 0,45$ & $4,04 \mathrm{c} \pm 0,45$ \\
\hline
\end{tabular}

Keterangan : Huruf yang sama dibelakang nilai rata-rata pada kolom yang sama menunjukkan perlakuan tidak berbeda nyata $(\mathrm{P}>0,05)$.

Kriteria skoring tekstur : 1. Sangat tidak berlendir, 2. Tidak berlendir, 3. Agak berlendir, 4. Berlendir, 5. Sangat berlendir Kriteria skoring aroma : 1. Sangat tidak asam, 2. Tidak asam, 3. Agak asam, 4. Asam, 5. Sangat asam

\section{Tekstur}

Hasil analisis ragam menunjukkan pesan tlengis lama penyimpanan pada suhu ruang berpengaruh nyata $(\mathrm{P}<0.05)$ terhadap tekstur. Tabel 8 menunjukkan nilai rata-rata skoring panelis terhadap tekstur berkisar $1,56-4,2$. Nilai tertinggi pada lama penyimpanan T3 (72 jam) sebesar 4,2 (berlendir) dan yang terendah pada lama penyimpanan T0 (0 jam) yaitu sebesar 1,56 (sangat tidak berlendir). Lama Penyimpanan T0 (0 jam), T1 (24 jam), T2 (48 jam) dan T3 (72 jam) berpengaruh nyata terhadap tekstur pesan tlengis.

Panelis memberikan respon semakin lama penyimpanan pesan tlengis pada suhu ruang menimbulkan tekstur yang berlendir. Tekstur akan berubah dengan adanya perubahan kadar air dalam produk pangan, kadar air adalah salah satu karekteristik yang sangat mempengaruhi penampakan, tekstur dan cita rasa dari produk pangan (Rospiati, 2007). Menurut Nurwantoro, (1997) dalam Arizona, et al., (2011) menyatakan bahwa hidrolisis protein oleh bakteri proteolitik menyebabkan perubahan tekstur pada produk.
Menurut Abraham, (1993) dalam Arizona, et al., (2011) menyatakan bahwa bakteri proteolitik merupakan bakteri yang mampu memproduksi enzim protease ekstraseluler, yaitu enzim pemecah protein yang diproduksi di dalam sel kemudian dilepaskan keluar sel. Tekstur pada pesan tlengis mengalami perubahan disebabkan oleh aktivitas mikroba dimana mikroba mampu hidup pada suhu optimum $25^{\circ} \mathrm{C}-30^{\circ} \mathrm{C}$

\section{Aroma}

Hasil analisis ragam menunjukkan lama penyimpanan pesan tlengis pada suhu ruang berpengaruh nyata $(\mathrm{P}<0,05)$ terhadap aroma. Pada Tabel 8, menunjukkan nilai rata-rata skoring panelis terhadap aroma berkisar 2,12-4,04. Nilai aroma tertinggi pada lama penyimpan T3 (72 jam) yaitu sebesar 4,04 (asam) dan terendah T0 (0 jam) yaitu sebesar 2,12 (tidak asam). Lama penyimpanan T0 (0 jam), T1 (24 jam), T3 (48 jam) dan T4 (72 jam) berbeda nyata terhadap aroma pesan tlengis pada penyimpanan suhu ruang.

Panelis memberikan respon semakin lama penyimpanan pesan tlengis pada suhu ruang 
menimbulkan aroma yang sangat asam oleh aktivitas mikroba dan adanya degradasi protein. Hal ini sejalan dengan Haerani, (2010) yang menyatakan bahwa blondo yang dihasilkan dari proses pembuatan VCO memiliki karakteristik berwarna putih, berbentuk krim, dan dalam waktu empat hari akan mengeluarkan bau yang tidak sedap dan sangat menyengat dikarenakan adanya aktivitas mikroba pada produk, sedangkan menurut Zuhra, (2006), perubahan aroma yang tidak diinginkan terjadi akibat gangguan dari mikroorganisme yang menghasilkan bau tidak sedap (off odors).

\section{KESIMPULAN DAN SARAN}

\section{Kesimpulan}

Lama penyimpanan suhu ruang berpengaruh pada perubahan karakteristik pesan tlengis, semakin lama penyimpanan maka kadar air mengalami peningkatan yang diakibatkan oleh kondisi lingkungan seperti suhu udara. Peningkatan kadar air diikuti dengan aktivitas mikroba dan kapang khamir yang mengakibatkan kadar abu, kadar protein dan kadar lemak mengalami penurunan karena mikroba membutuhkan nutrisi untuk berkembang biak, dengan tingginya mikroba dan kapang khamir selama penyimpanan maka berpengaruh pula sifat sensori aroma dan tekstur.

Hasil penelitian pesan tlengis selama penyimpanan pada suhu ruang, perlakuan lama penyimpanan 24 jam merupakan perlakuan yang masih bisa untuk dikonsumsi dengan nilai kadar air 5,04\%, kadar abu 3,55\%, kadar protein 13,77\%, kadar lemak $55,83 \%$, kadar karbohidrat $21,79 \%$, angka lempeng total mikroba 5,99 log cfu/g, angka kapang khamir $0 \log \mathrm{cfu} / \mathrm{g}$, aroma agak asam, dan tekstur tidak berlendir.

\section{Saran}

Berdasarkan hasil penelitian, disarankan dalam pembuatan pesan tlengis dapat ditambahkan proses pengukusan dan menyimpan pesan tlengis pada suhu ruang tidak lebih dari 24 jam, dikarenakan jika melebihi waktu tersebut dapat menimbulkan kerusakan pada produk.

\section{DAFTAR PUSTAKA}

Ahmad, R.Z.2005. Pemanfaatan khamir sacchomyces cerevsiae untuk ternak. Watozoa. 15 (1) : 49-55.

Anonimus. 2019. Hasil Wawancara: Jenis dan Cara Pengolahan Pesan Tlengis. Kecamatan Denpasar Barat.

Arizona, R., E. Suryanto dan Y. Erwanto, 2011. Pengaruh Konsentrasi Asap Cair Tempurung Kenari dan Lama Penyimpanan Terhadap Kualitas Kimia dan Fisik Daging. Jurnal Buletin Peternakan. 35(1):50-56.

Buckle, K.A, R.A. Edwards, G.H. Fleet and M. Wootton. 1987. Ilmu Pangan. Diterjemahkan oleh Hari Purnomo dan Adiono. UI Press. Jakarta. 365 hlm.

Cappuccino, JG. dan N. Sherman. 1992. Microbiology: A Laboratory Manual. The Benjamin/Cummings Publishing Company,Inc. Clifornia.

Dyah, L.D.A. 2017. Faktor-Faktor Penyebab dan Karakteristik Makanan Kadaluarsa yang Berdampak Buruk pada Kesehatan Masyarakat. APIKES Citra Medika Surakarta.

Fatimah, E. Aldhani dan D. Sandri. 2016. Otimasi Suhu dan Lama pengukusan untuk memperpanjang Umur Simpan Getuk Pisang Rainbow. Jurnal Teknologi Agro-Industri 3(2):halaman-selesai

Gomes, K.A, dan A.A. Gomes. 1995. Prosedur statistik untuk penelitian pertanian. UI Press, Jakarta.

Haerani. 2010. Pemanfaatan Limbah Virgin Coconut Oil (Blondo). J. MKMI., 6(4), 244-248.

Kusrahayu, H. Rizqiati, S. Mulyani. 2009. Pengaruh Lama Penyimpanan Krim Susu yang Ditambahkan Ekstrak Kecambah Kacang Hijau Terhadap Angka Thiobarbituric Acid (TBA), Kadar Lemak dan Kadar Protein. Semarang.

Julinar. Lidya, E., Fatma. 2005. Pengaruh Proses Pengukusan Terhadap Daya Awet Rendang Daging Sapi yang Dikemas. Universitas Sriwijaya. 
Lawalata, V.N., Budiastra, I.W., Hayanto.B. 2004. Peningkatan Nilai Gizi Organoleptik dan Fisik Sagu Mutiara Dengan Penambahan Buah Kenari (Canarium ovatum). Vol 24 No 9-16. Agritech.

Lewis, MJ. 2006. Dalam Pratama, R.I, Rostini, I., Rochima, E. 2018. Profil Asam Amnio, Asam Lemak dan Komponen Volatil Ikan Gurame Segar (Osphronemus gouramy) dan Kukus. Universitas Padjadjaran. Sumedang Jawa Barat

Misbah. A. I.K. Suter, I.D.P.K.Pratiwi. 2015. Kajian Mutu dan Keamanan Pangan Tradisional Sate Bulayak di Taman Wisata Suranadi, Kecamatan Narmada, Kabupaten Lombok Barat. Vol 4 No 2. Itepa.

Purnawijayanti, H.A.2001. Sanitasi, Higiene dan Keselamatan Kerja dalam Pengolahan Makanan. Yogyakarta: Kanisius.

Putri, J., S. Haryanti, M. Izzati. 2017. Pengaruh lama penyimpanan terhadap perubahan morfologi dan kandungan gizi pada umbi talas bogor (Colocasia esculenta(L.) Schott). Jurnal Biologi. Universitas Diponegoro, Semarang.

Sipayung, M.Y., Suparmi, Dahlia. 2015. Pengaruh Suhu Pengukusan Terhadap Sifat Fisik Kimia Tepung Ikan Rucah. Jurnal Fakultas Perikanan dan Kelautan Universitas Riau 1(2).S

Soekarto, S.T.1985. Penilaian Organoleptik untuk Industri Pangan dan Hasil Pertanian. Pusat Pengembangan Teknologi Pangan, IPB, Bogor.

Soputan, D.D., Mamuaja, C.F.,Lolowang.T.F.2016.Uji Organoleptik dan Karakteristik Kimia Produk Klappertaart di Kota Manado Selama Penyimpanan.Universitas Samratulangi, Manado. 2(1)

Standar Nasional Indonesia. 1996. Kue Basah. SNI: 014309-1996. Badan Standarisasi Nasional.

Waluyo, L., 2004. Mikrobiologi Umum Univeristas Muhamadiyah Malang Press, Malang

Winarno, F.G dan Betty J.S.L. 1983. Kerusakan Bahan Pangan dan Cara Pencegahannya. Penerbit. Ghalia Inodonesia. Jakarta.

Winarno, F.G. 1994. Makanan Tradisional dan Pengembangannya. Paper disampaikan pada pelatihan tenaga PKK dalam pengembangan pangan tradisional, Denpasar.

Winarno FG. 1997. Kimia Pangan dan Gizi. Jakarta: Gramedia Pustaka Utama.

Zuhra, C. F. 2006. Flavor (Citarasa). Departemen FMIPA Universitas Sumatera Utara, Sumatera Utara. 